\title{
Melanosis of the uterine cervix: a case report and literature review
}

\section{Melanose cervical uterina: relato de caso e revisão da literatura}

Daniel Chang무 Gerusa Biagione Tiburzio²

\begin{abstract}
Melanosis of the uterine cervix is an extremely rare melanocytic lesion and should be differentiated from melanoma. It is a melanocytic hyperpigmentation of basal layer cells from the squamous mucosa of the uterine cervix without an increase in the number of melanocytes. We present a typical case of this entity. Furthermore, we discuss the possible origins of melanocytes in this region and their association with Laugier-Hunziker syndrome and Carney complex.
\end{abstract}

Key words: melanosis; uterine cervix; melanoma.

\section{INTRODUCTION}

Melanocytic pigmented lesions of the uterine cervix are extremely rare. Blue nevus and melanomas are among the most commonly found. However, there are occasional reports of cervical uterine melanosis that in terms of histology correspond to the melanotic hyperpigmentation of basal layer cells from the squamous epithelium without increase in the number of local melanocytes. A review of the English literature revealed only 12 cases reported to date de, $^{(2,6-8,15,16,18)}$.

Accordingly, we report a typical case of this entity with the aim to acquaint pathologists with this finding. Furthermore, we describe the possible origin of melanocytes in this site and the syndromes that may be related to this finding, namely LaugierHunziker syndrome and Carney complex.

\section{CASE REPORT}

39-year old white female patient, who had never got pregnant, underwent routine colposcopy. The exam revealed an oval-shaped blackish-brown flat area on the anterior lip of the uterine cervix (between 10 and 11 hours), measuring $1 \times 0.5 \mathrm{~cm}$ and presenting no change after applying acetic acid 3\% (Figure 1). The Schiller test was negative. No changes were observed in the vagina and vulva. The cervicovaginal cytology was normal. There was no genital or systemic pathological history.

Biopsy of the ectocervical mucosa lesion revealed squamous epithelium without atypia, deposition of melanin pigments in the basal layer resulting in hyperpigmentation and no significant increase in melanocytes (Figures 2 and 3). Considering these findings, the diagnosis of uterine cervical melanosis was established.

Thus, we proceeded to complete resection of the lesion with safety margins. After a two-year follow up, there was no recurrence and/or appearance of new lesions.

\section{DISCUSSION}

The uterine cervical melanosis is an extremely rare benign melanocytic lesion with few cases described in the literature ${ }^{(2,4,6-8,15,16,18)}$. It is usually identified during routine gynecological examination. However, even when the cytology

First submission on 09/04/13; last submission on 01/05/13; accepted for publication on 03/05/13; published on 20/06/13

1. Doctor and Master's in Medicine by Universidade de São Paulo (USP); pathologist at Laboratório Diagnóstika - Patologia Cirúrgica e Citologia.

2. Medical residence in Pathology at Pontifícia Universidade Católica (PUC-Campinas); pathologist at Laboratório Diagnóstika - Patologia Cirúrgica e Citologia 


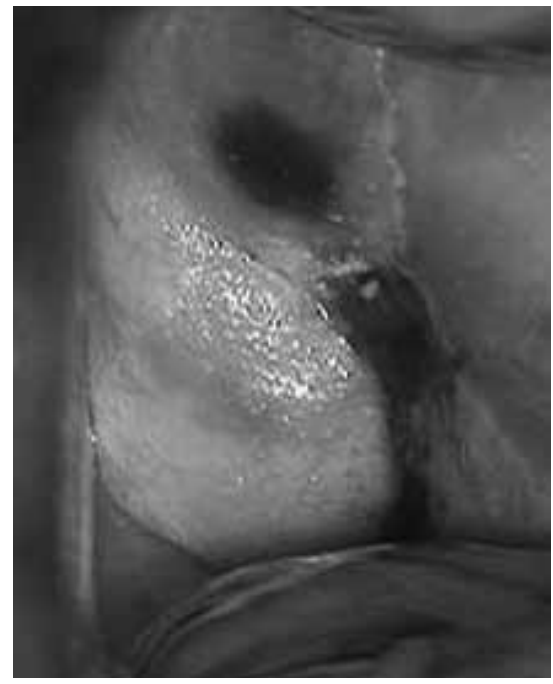

FIGURE 1 - Colposcopy showing pigmented lesion on the anterior lip of the uterine cervix (16x)

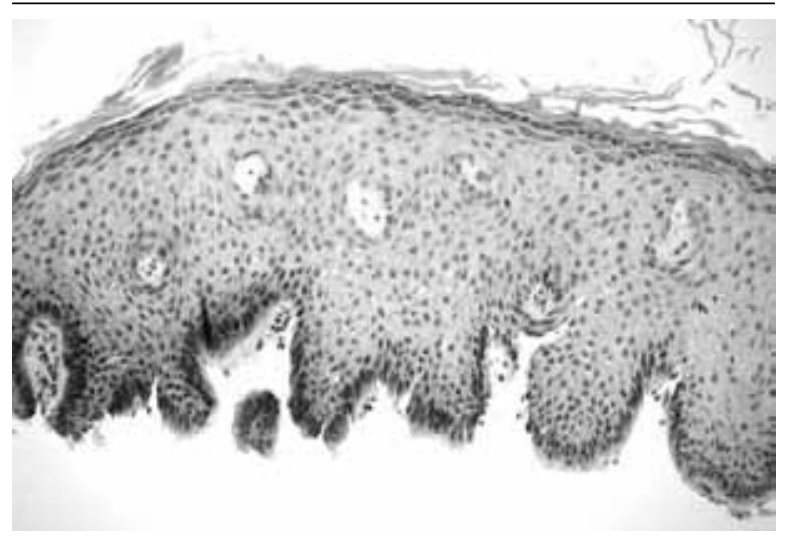

FIGURE 2 - Squamous mucosa of the uterine cervix with hyperpigmentation of basal layer cells without increase in melanocytes (HE, 100×) HE: hematoxylin and eosin.

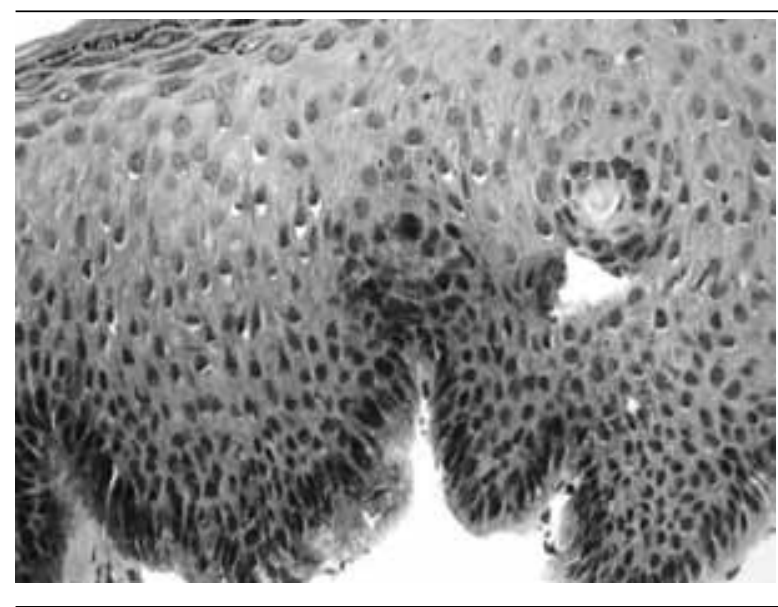

FIGURE 3 - Magnified image of squamous mucosa of the uterine cervix with byperpigmentation of basal layer cells without increase in melanocytes (HE, 200×) HE: hematoxylin and eosin. is normal, a biopsy is mandatory when the colposcopic examination reveals a blackish-brown area. This procedure is recommended in order to exclude the diagnostic hypothesis of cervical melanoma, which has a high mortality rate in spite of being extremely rare $^{(2,4,9)}$

This case presents great similarities with other studies reported in the literature. It is a flat and pigmented lesion on the cervix that displays only melanocytic hyperpigmentation in basal layer cells from the squamous mucosa without melanocytic proliferation ${ }^{(2,4,6-8,15,16,18)}$. Moreover, they were all incidental findings during routine gynecological examination or otherwise unrelated to the pigmented lesion, namely investigation of primary infertility ${ }^{(15)}$, menorrhagia ${ }^{(7)}$ or uterine $\operatorname{prolapse}^{(8)}$. Finally, all cases reported in the literature, as well as the one described herein, showed no recurrence after surgical resection.

The origin of melanocytes in cervical pigmented lesions has not been well established yet. There are basically two hypotheses proposed in the literature ${ }^{(15)}$. In the first one, it is speculated that they result from the migration of elements from the neural crest or melanocyte migration from adjacent mucocutaneous areas. The other possibility would be the result of transformation of the cervical squamous epithelium, which resembles the epidermis, in response to chronic irritation or trauma ${ }^{(18)}$. Therefore, some authors have described the development of melanosis in the cervix as a result of cryotherapy for cervical dysplasia ${ }^{(6)}$ and in patients with long-term uterine prolapse ${ }^{(8)}$.

Regarding the incidence of melanocytes in uterine cervical mucosa, there are few reports in the literature. Carinelli et al. mention the presence of melanocytes in $1.7 \%$ of 466 examined uterine cervices ${ }^{(3)}$. Uehara et al. found melanocytic foci in $28.6 \%$ of 189 analyzed uteri ${ }^{(17)}$.

It is noteworthy that the term melanosis refers to hyperpigmented lesions, but without increase in the number of melanocytes, as it is reported herein. When there is an increase in melanocytes in these pigmented lesions, it is preferable to denominate it lentiginosis. However, this distinction has no practical prognostic implications ${ }^{(1,11)}$. Furthermore, in the presence of melanosis in the genital area, the possibility of LaugierHunziker syndrome (idiopathic mucocutaneous lenticular pigmentation), which is characterized by the presence of genital melanosis associated with melanocytic lesion in the oral cavity, should be excluded ${ }^{(5,10,12)}$. Another possible association refers to Carney complex, that is to say pigmented lesions with atrial myxoma and multiple endocrine neoplasias ${ }^{(13,14)}$.

In the present case, the patient did not report any treatment or previous infection, which precludes the attempt to identify a 
causal factor for this lesion. Moreover, no other lesions (oral, heart or other organs) had been reported. Nevertheless, regardless of the origin of melanocytes, the finding of pigmented lesions on the cervix should be clarified as soon as possible in order to exclude the hypothesis of cervical melanoma and association with other lesions that may be part of a syndrome or complex.

\section{RESUMO}

A melanose cervical uterina representa lesão melanocítica extremamente rara, devendo ser diferenciada do melanoma. Trata-se de uma hiperpigmentação melanocítica das células da camada basal da mucosa escamosa do colo uterino sem aumento no número de melanócitos. Apresenta-se, neste artigo, um caso característico dessa entidade, além da discussão acerca das possíveis origens dos melanócitos nessa região, bem como sua relação com a síndrome de Laugier-Hunziker e o complexo de Carney.

Unitermos: melanose; colo uterino; melanoma.

\section{REFERENCES}

1. BARNHILL, R. L.et al. Genital lentiginosis: a clinical and histopathologic study.JAm Acad Derm, v. 22, p. 453-60, 1990.

2. BARTER, J. F. et al. Melanosis of the cervix. Gynecol Oncol, v. 29, n. 1, p. 101-4, 1988.

3. CARINELLI, S. G.; PRAT, J.; ROBBOY, S. J. Blue nevus of the cervix. Tumori, v. 64, p. 95-8, 1978.

4. DEPPISCH, L. M. Cervical melanosis. Obstet Gynecol, v. 62, n. 4, p. 525-6, 1983.

5. GERBIG, A. W.; HUNZIKER, T. Idiopathic lenticular mucocutaneous pigmentation or Laugier-Hunziker syndrome with atypical features. $A r c h$ Dermatol, v. 32, p. 844-5, 1996.

6. HYTIROGLOU, P.; DOMINGO, J. Development of melanosis of uterine cervix after cryotherapy for epithelial dysplasia. Am J Clin Pathol, v. 93, n. 6, p. $802-5,1990$.

7. KAPLAN, P. A.; GRIFFO, M. D.; DIAZ-ARIAS, A. A. Melanosis of the uterine cervix: a case report. J Reprod Med, v. 50, n. 11, p. 867-70, 2005.

8. KAPOOR, N. K. Melanosis of the uterine cervix: a report of two cases. Indian J Pathol Microbiol, v. 46, n. 1, p. 102-3, 2003.

9. KRISTIANSEN, S. B.; ANDERSON, R.; COHEN, D. M. Primary malignant melanoma of the cervix and review of the literature. Gynecol Oncol, v. 47, p. 398-403, 1992.
10. LAUGIER, P.; HUNZIKER, N.; OLMOS, L. Pigmentation melanique lenticulare essentialle de la muqueuse jugale et des levres.Ann Dermatol Venereol, v. 104, p. 181-4, 1977.

11. LENANE, P. et al. Genital melanotic macules: clinical, histologic, immunohistochemical and ultrastructural features. J Am Acad Dermatol, v. 42, p. 640-4, 2000.

12. LENANE, P. et al. The Laugier-Hunziker syndrome.J Eur Acad Derm Venereol, v. 15, p. 574-7, 2001.

13. REED, 0. M.; MELLETTE, J. R.; FITZPATRICK, J. E. Cutaneous lentiginosis with atrial myxomas. J Am Acad Dermatol, v. 15, p. 398$402,1986$.

14. RHODES, A. R. et al. Mucocutaneous lentigines, cardiomucocutaneous myxomas and multiple blue nevi: the LAMB syndrome. J Am Acad Dermatol, v. 10, p. 72-82, 1986.

15. SAIKIA, U. N. et al. Melanin containing cells of the uterine cervix and a possible histogenesis: a case report. Indian J Pathol Microbiol, v. 47, n. 1, p. 22-3, 2004.

16. TSUKADA, Y. Benign melanosis of the vagina and cervix. Am J Obstet Gynecol, v. 124, p. 211-2, 1976.

17. UEHARA, T. et al. Stromal melanocytic foci (blue nevus) in step sections of the uterine cervix. Acta Pathol Jpn, v. 41, p. 751-6, 1991.

18. YILMAZ, A. G. et al. Melanosis of the uterine cervix: a report of two cases and discussion of pigmented cervical lesions. Int J Gynecol Pathol, v. 18, n. 1, p. 73-6, 1999. 